\title{
CURRENT LIABILITIES AND THEIR ACCOUNTING IN THE ATTRACTED CAPITAL MANAGEMENT SYSTEM
}

\author{
Olena Podolianchuk', Tetiana Plakhtii ${ }^{2}$, Nataliya Gudzenko
}

\begin{abstract}
The purpose of the article is to reveal the essence of the attracted capital, to clarify the legal, economic, and legal content of the liabilities, to justify the relationship between the categories of "liabilities", "arrears", "calculations" and "liabilities" and "attracted capital", assess domestic and foreign experience in the classification of liabilities, justify information management of the attracted capital, taking into account the step-by-step accounting process of current liabilities, introduce proposals for the classification of current liabilities with the aim to improve the management of current liabilities as a part of debt capital. Methodology. The methodological basis for the disclosure of the research goal was the scientific advancement of scientists, legislative and regulatory acts on issues of accounting obligations. Results. The study found that, in the conditions of unstable economic development, one of the important tasks of enterprise management is a rational choice of the asset formation sources structure. The article reveals the essence of the term "capital" and it is found out that the basis of the definition is the material-real form. Problems of the contents of attracted and borrowed capital are outlined. The study of legislative documents, which defined the content of the category "liabilities", was conducted. Legal components of current liabilities characteristic are explored and discussed issues are defined. The legal and economic aspects of liabilities are investigated. As a result of the research, the theoretical substantiation of the essence of the categories "liabilities", "debt" and "settlements" was conducted. It is proved that all current liabilities are divided into real and potential ones. The order of displaying information about current liabilities at all stages of the accounting process is substantiated. It is confirmed that the basis of the management accounting for the attracted capital is the primary documents, accounting data, and generalized forms of internal and external reporting. Practical implication. The analytical data of the composition and the structure of attracted capital of agricultural enterprises with detailed analysis of structure of current liabilities are presented. It is confirmed that liabilities occupy a significant share in the structure of capital and are a source of economic activity financing of enterprises. It is determined that not all liabilities arising in civil and commercial law are recorded in the accounts. We substantiated the characteristic features of liabilities. It is determined that all liabilities that are the subject of accounting are legal and economical. The opinion on the content of the definition of "commitment" is taken into account with the accounting, economic, and legal constituents. As a result of the study of foreign experience in the classification of current liabilities, the author's interpretation of the classification of current liabilities is presented. Value/originality. An important objective for the management system is the objective classification of liabilities, their assessment and reliability of accounting. It is proposed to distinguish certain classifications of current liabilities for the purpose of managing borrowed capital in terms of current liabilities.
\end{abstract}

Key words: attracted capital, indebtedness, settlements, current liabilities, accounting.

JEL Classification: M21, M41

\section{Introduction}

In the activities of business entities inevitably there are interconnections with different contractors. This is due to the requirements of the business and the market.

Corresponding author:

${ }^{1}$ Vinnytsia National Agrarian University, Ukraine.

E-mail: podolianchuk_1@i.ua

ORCID: https://orcid.org/0000-0003-0234-8943

${ }^{2}$ Vinnytsia National Agrarian University, Ukraine.

E-mail: taniprof@i.ua

ORCID: http://orcid.org/0000-0002-5379-1577

${ }^{3}$ Vinnytsia National Agrarian University, Ukraine.

E-mail: gudzenko_nm@i.ua

ORCID: http://orcid.org/0000-0002-0978-4257
There is the implementation of economic processes and, as a consequence, the emergence of relationships in the middle of the company and beyond. In other words, in each enterprise there are calculations, it can 
have debts and certain liabilities to contractors. The state of payments, the timeliness of debt repayment, the completeness and quality of performance of liabilities characterize the business reputation of the enterprise, its plateau and credit, as well as financial stability in general. Therefore, it is important not whether the company has an obligation, but what is its share in the attracted capital and how to implement effective management. In view of this, the significance for the management system is the semantic load, the correct classification of liabilities, their assessment, and reliability of accounting.

\section{Brief literature review}

The work on the content of liabilities as an object of accounting, analysis, and control deals with the works of many domestic scientists, in particular: N. P. Mykhaylyshyn (Mykhaylyshyn, 2012), O. O. Zelenina (Zelenina, 2012), O. B. Chornenka (Chornenka, 2017), N. V. Potryvaeva (Potryvayeva, 2016), O. M. Petruk (Petruk, 2012), Yu. Yu. Myronova (Myronova, 2016), L. V. Chyzhevska (Chyzhevska, 2011), N. R. Dombrovska (Dombrovska, 2014), V. O. Hanusych (Hanusych, 2015), V. M. Rasenko (Rasenko, 2012), L. L. Gevlych (Gevlych, 2017), as well as significant contribution to development accounting system of liabilities is made by the following foreign experts: Shaista Wasiuzzaman (2015), Ala'a Adden Abuhommous (2017), Jiri Chod (2017), Katarzyna Świetla (2015), Richard Barker and Anne McGeachin (2013).

Paying tribute to the scientific developments in the theory and practice of accounting liabilities, some aspects require further study, systematization, and clarification. Controversy over the essence of categorical apparatus predetermines the need for interpretation of liabilities from the legal, economic and accounting point of view. A variety of classification criteria for liabilities requires a generalization of their classification for the needs of users of information. Different approaches to recognizing liabilities require further research to assess their compliance with accounting principles (business continuity, historical (actual) cost and prudence). All this testifies to the relevance of the chosen topic of the study and the need for systematization, refinement, improvement of the theoretical and methodological provisions of accounting liabilities.

\section{Current liabilities in the structure of attracted capital}

To reveal the content of the topic under consideration, first of all, we note that the management of capital - is the adoption of managerial decisions related to the definition of the optimal sources of its formation and the policy of rational use in the process of various activities.

The research of scientific literature shows that the term "capital" has an ambiguous interpretation. In a broader sense, capital is characterized as all sources of enterprise assets formation. Hence, this definition is used in relation to both sources of capital formation and assets. Characterizing the sources, distinguished by "passive capital", which is divided into own and borrowed (borrowed), and characterizing assets - about "active capital", dividing it into main (non-current assets) and working capital (stocks, cash, accounts receivable, etc.). In a more narrow definition of capital - it is expressed in the value of fixed and working capital. In this case, capital as aggregate resources used in business represents its material and material basis.

Shaista Wasiuzzaman determines that the relationship of working capital (and its components) with profitability may not be as simple as it seems and may be dependent on other influences such as economic policy (Wasiuzzaman, 2015).

The disclosure of the nature of capital and its characteristics are complicated by the presence of many classifications and types of capital. In scientific publications, there are discussions about the nature of borrowed and borrowed capital. All of this, in our opinion, is explained by the linguistic characteristics of terminology. To understand the essence of these concepts, we turn to the academic explanatory dictionary. Involve means to use something somewhere, and borrow to borrow something from someone; take something for someone in temporary use; to give something to someone else (Academic Explanatory Dictionary).

The substantiation of the essence of the enterprise capital is closely connected with the definition of its composition and structure, as evidenced by statistical data (Table 1).

According to the State Statistics Service of Ukraine, there is a situation of annual growth in the size of current liabilities of enterprises in all sectors of the economy (Figure 1). This situation shows that entrepreneurs do not have their own funds to ensure the continuity of activities and are forced to resort to external sources.

As N.P. Mykhailyshyn notes, the presence of obligations is considered a normal state of any operating company since they are the basis of the relationship between economic entities (Mykhaylyshyn, 2012).

In addition, the firm's management should be aware of the importance of trade credit to finance sales growth (Abuhommous, 2017).

A supplier who automatically monitors the number of orders ... may restrain the risk of looking for seller behaviour with the threat of more stringent lending conditions. It provides suppliers with a financial advantage over banks... (Chod, 2017).

In the present economy, it is essential to access the correct information coming from the market. The source of such information is financial statements of entities, prepared in accordance with accepted accounting principles and ethical behaviour requirements (Katarzyna, 2015). 
Vol. 5, No. 3, 2019

Table 1

Current liabilities and support of Ukrainian enterprises*

\begin{tabular}{|c|c|c|c|c|c|c|c|c|c|c|}
\hline \multirow{3}{*}{ Current liabilities and support } & \multicolumn{10}{|c|}{ State on } \\
\hline & \multicolumn{2}{|c|}{31.12 .2012} & \multicolumn{2}{|c|}{31.12 .2013} & \multicolumn{2}{|c|}{31.12 .2014} & \multicolumn{2}{|c|}{31.12 .2015} & \multicolumn{2}{|c|}{31.12 .2016} \\
\hline & $\begin{array}{l}\text { UAH } \\
\text { million }\end{array}$ & $\%$ & $\begin{array}{l}\text { UAH } \\
\text { million }\end{array}$ & $\%$ & $\begin{array}{l}\mathrm{UAH} \\
\text { million }\end{array}$ & $\%$ & $\begin{array}{l}\text { UAH } \\
\text { million }\end{array}$ & $\%$ & $\begin{array}{l}\mathrm{UAH} \\
\text { million }\end{array}$ & $\%$ \\
\hline Total & 2472841,7 & 100 & 2689338,2 & 100 & 3151253,0 & 100 & 4114903,2 & 100 & 5846688,7 & 100 \\
\hline \multicolumn{11}{|l|}{ Including: } \\
\hline Short-term bank credits & 316987,2 & 13 & 371760,5 & 14 & 428243,2 & 14 & 455709,4 & 11 & 496947,2 & 9 \\
\hline current debt for long-term liabilities & 90788,7 & 4 & 100649,8 & 3 & & & & & & \\
\hline payables & 2065065,8 & 83 & 2169850,8 & 81 & 1733245,0 & 55 & 2196263,4 & 53 & 2587426,8 & 44 \\
\hline current security & & & 15166,8 & 1 & 45794,7 & 1 & 30456,8 & 1 & 59357,8 & 1 \\
\hline $\begin{array}{l}\text { future income and deferred } \\
\text { commission income from reinsurers }\end{array}$ & & & 31910,3 & 1 & 29025,8 & 1 & 31486,1 & 1 & 37109,7 & 1 \\
\hline Other current liabilities & & & & & 914944,3 & 29 & 1400987,5 & 34 & 2665847,2 & 45 \\
\hline
\end{tabular}

* Data are given without taking into account the results of activity of banks and budgetary institutions on the temporarily occupied territory of the Autonomous Republic of Crimea, the city of Sevastopol and part of the zone of anti-terrorist operation

Source: State Statistics Service

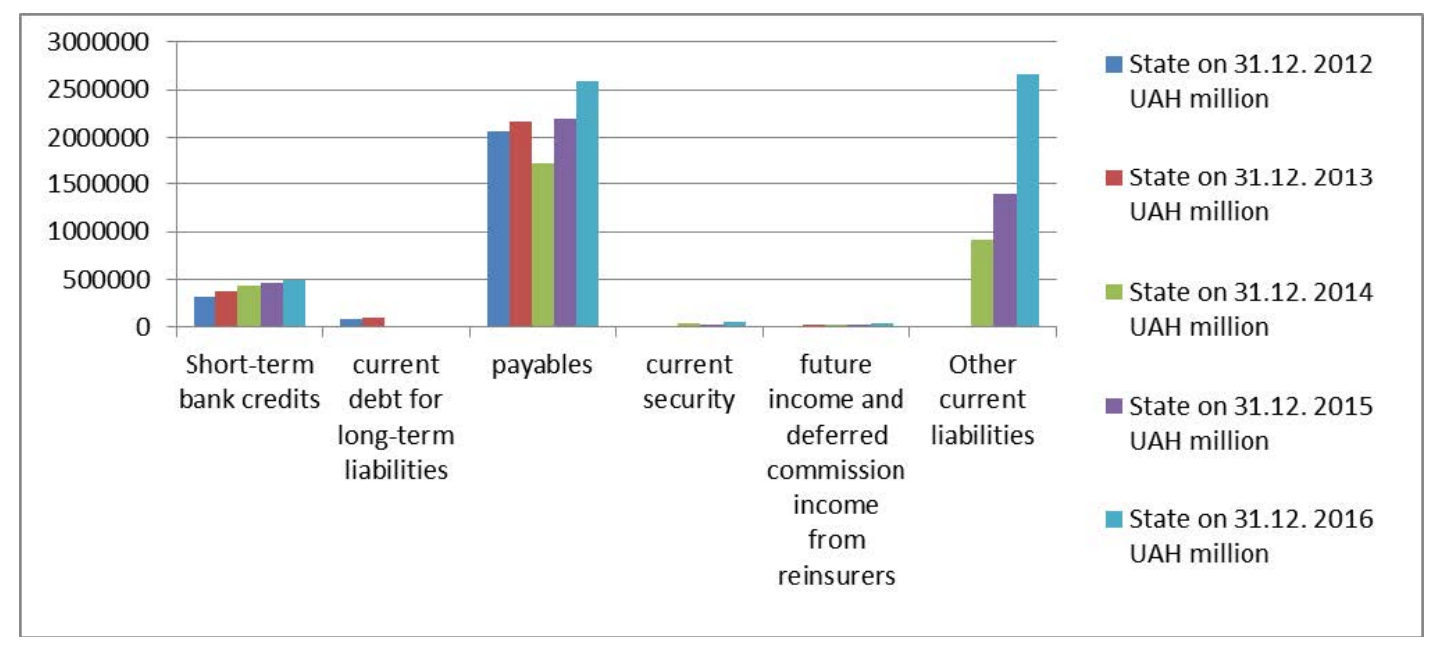

Figure 1. Dynamics of current obligations of enterprises of Ukraine, million UAH

Source: State Statistics Service

To support the given opinion, we will present an analysis of the composition and structure of the liabilities of agricultural enterprises (Table 2). The analysis confirms that in today's situation, when currency fluctuations occur, enterprises operate at risk, without the involvement of additional resources, it is impossible to carry out activities.

Summarizing the calculations, the data can be argued that the obligation in the structure of sources of formation of the property of the enterprises under study occupies from $1 \%$ to $76 \%$ (Figure 2). All this again confirms the objectivity of "attracting resources from the side" but, at the same time, it is necessary to manage the attracted capital rationally.

As we can see from Figure 2, attracted capital, in the form of liabilities, is an important source of financing of economic activities of enterprises, it significantly affects their financial position, and therefore, there is a need for efficient management of cash flows, settlement operations, arrears, etc.

From the accounting-economic point of view and from the position of management, O. O. Zelenina substantiated the need to withdraw from the stock of attracted capital of third-party and loan capital. To third-party capital is assigned - accounts payable for goods, works, services, advances received deferred payments, promissory notes issued, settlement liabilities, loans - long-term and short-term loans of financial institutions, bond loans, financial lease liabilities, turnaround financial assistance, funds received as a result of factoring transactions (Zelenina, 2012). The author's opinion is justified, as it enables the identification and structuring of accounting objects related to the attracted capital. 
Table 2

Analysis of composition and structure of attracted capital, thousand UAH

\begin{tabular}{|c|c|c|c|c|c|c|}
\hline \multirow{2}{*}{ Indexes } & \multicolumn{2}{|c|}{2015} & \multicolumn{2}{|c|}{2016} & \multicolumn{2}{|c|}{2017} \\
\hline & thousand UAH & $\%$ & thousand UAH & $\%$ & thousand UAH & $\%$ \\
\hline \multicolumn{7}{|c|}{ LTD "Peremoga" } \\
\hline Equity & 13191,9 & 99 & 17093,5 & 98 & 21749,8 & 95,5 \\
\hline Liabilities: & 144,6 & 1 & 379,6 & 2 & 113,5 & 0,5 \\
\hline \multicolumn{7}{|l|}{ Current payables for: } \\
\hline goods, work, services & 144,6 & 1 & 183,2 & 1 & 67,2 & 0,3 \\
\hline Other current commitments & & & 196,4 & 1 & 46,3 & 0,2 \\
\hline Balance & 13336,5 & 100 & 17473,1 & 100 & 21863,3 & 100 \\
\hline \multicolumn{7}{|c|}{ LTD "Ahroposluhtransservis" } \\
\hline Equity & 12821,8 & 65 & 16448,0 & 66 & 23388,0 & 68 \\
\hline Liabilities: & 7034,6 & 35 & 8297,3 & 34 & 10947,7 & 32 \\
\hline $\begin{array}{l}\text { Long-term liabilities, targeted financing } \\
\text { and provision }\end{array}$ & 4600,0 & 23 & 4493,0 & 18 & 4608,0 & 13 \\
\hline \multicolumn{7}{|l|}{ Current payables for: } \\
\hline goods, work, services & 2350,7 & 12 & 2253,1 & 9 & 3681,9 & 11 \\
\hline calculations with the budget & 39,4 & 0,2 & & & 38,9 & 0,1 \\
\hline insurance calculations & 5,4 & 0,03 & & & & \\
\hline payroll calculations & 39,1 & 0,2 & 33,2 & 0,1 & 62,5 & 0,2 \\
\hline Other current liabilities & & & 1518,0 & 7 & 2556,4 & 8 \\
\hline Balance & 19856,4 & 100 & 24745,3 & 100 & 34335,7 & 100 \\
\hline \multicolumn{7}{|c|}{ JVF “Lan” } \\
\hline Equity & 253,9 & 29 & 366,0 & 48 & 453,4 & 24 \\
\hline Obligation: & 625,3 & 71 & 398,9 & 52 & 1773,3 & 76 \\
\hline long-term bank credits & 150,0 & 17 & 83,3 & 11 & 16,6 & 1 \\
\hline Short-term bank credits & & & 37,5 & 5 & 412,3 & 21 \\
\hline Current payables for goods, works, services & 117,1 & 13 & 256,6 & 33 & 725,2 & 38 \\
\hline Other current commitments & 358,2 & 41 & 21,5 & 3 & 319,2 & 16 \\
\hline Balance & 879,2 & 100 & 764,9 & 100 & 1926,7 & 100 \\
\hline
\end{tabular}

Source: according to the form N1 of business entities

\section{Normative legal substantiation and scientific approaches to the content of the studied categories}

Note that in the accounting standards, the definition of capital is absent, only the following terms are treated: - equity - the difference between assets and liabilities of the enterprise;

- assets - resources controlled by the enterprise as a result of past events, the use of which is expected to result in future economic benefits;

- liabilities - debts of an enterprise that arose as a result of past events and whose recovery in the future is expected to lead to a reduction in the resources of the enterprise embodying economic benefits (National Accounting Provision (Standard) 1).

Thus, it can be argued that liabilities in various forms of engagement are used to carry out the business activities of an enterprise.
Formation of views on the category of commitment has a long history but the economic literature covers different approaches to the essence of the study definition. There is no refutation in the normative documents (Table 3 ).

Richard Barker and Anne McGeachin point out that International Financial Reporting Standards are inconsistent with respect to the recognition and measurement of liabilities, both in the conceptual framework for financial reporting and in accounting standards themselves (Richard \& McGeachin, 2013).

According to N.P. Mykhailyshyn, not all liabilities that arise in civil and commercial law are recorded in the accounts. Isolation from the whole complex of liabilities of the enterprise of their limited part, which is reflected in the financial statements, provides for the qualification of a number of liabilities of economic entities for the purposes of accounting as conditional (Mykhaylyshyn, 2012). 
Vol. 5, No. 3, 2019

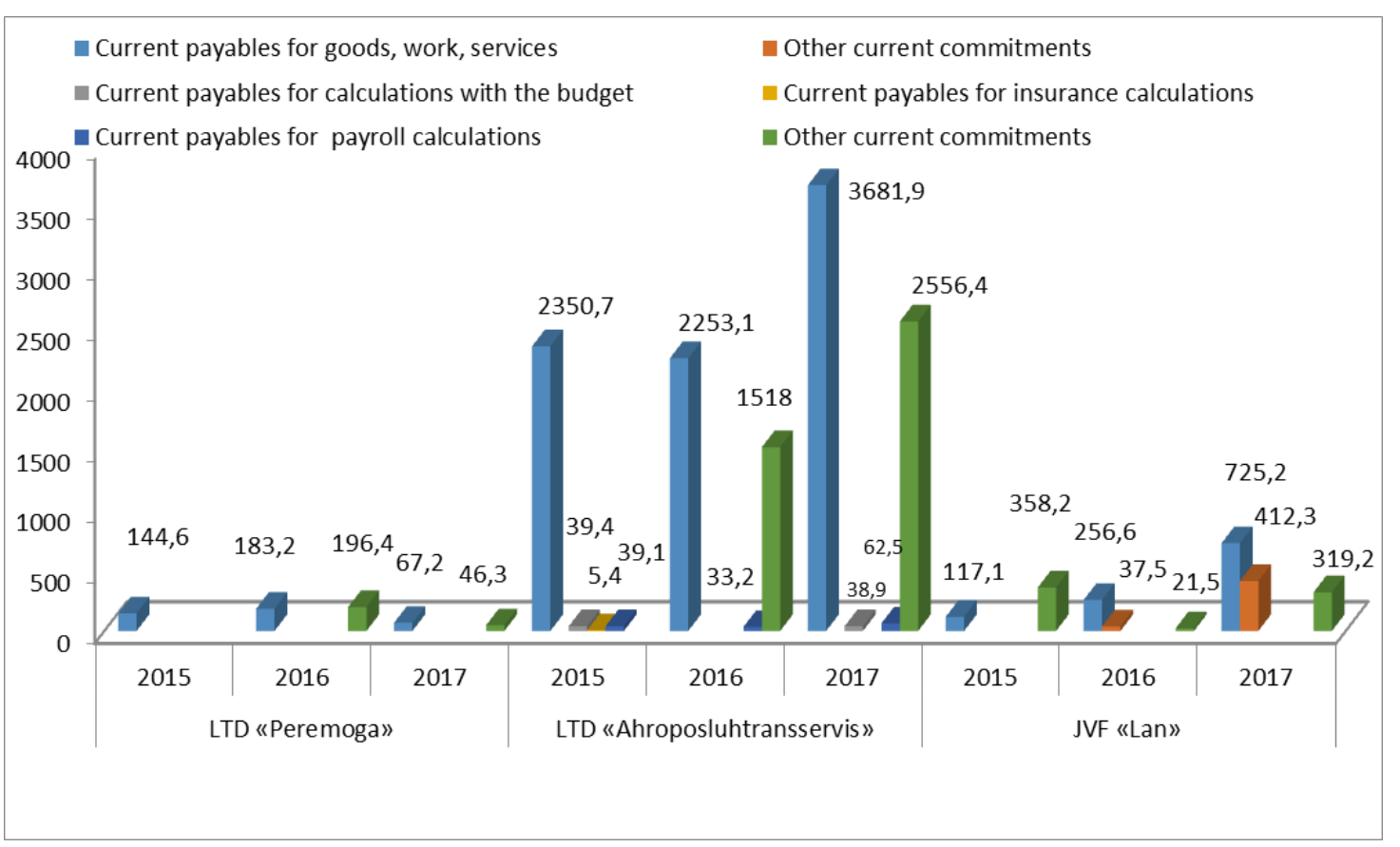

Figure 2. Structure of current liabilities

Source: according to economic entities

Our research gives grounds to substantiate the view that most researchers characterize the nature of the liabilities in accordance with the specifics of the field of their research. Therefore, the scientific literature reveals the economic and legal aspects of the liabilities.

In domestic practice, the notion of "liability" from the legal point of view prevails. As a legal category, an economic obligation is a business relationship governed by law. By virtue of the existence of these relations, one party is authorized to require another business transaction: transfer of property, performance of works, provision of services, and the other party is required to comply with the requirements of the subject of the obligation and, with this, the right to demand an appropriate remuneration - payment of funds, counter services. Thus, the essence of the obligation is the rights and liabilities of the parties. For example, in a sales contract, the buyer has the right to demand from the seller to transfer the purchased goods to him. This buyer's right corresponds to the

Table 3

Determination of liabilities in normative documents

\begin{tabular}{|l|l|}
\hline \multicolumn{1}{|c|}{ Normative document } & \multicolumn{1}{c|}{ Definition } \\
\hline The Commercial Code of Ukraine & $\begin{array}{l}\text { A business recognized as a liability that arises between a business entity and another } \\
\text { participant (participants) in a business relationship based on the grounds provided for by the } \\
\text { Economic Code, in virtue of which one entity (obliged to be a party, including the debtor) } \\
\text { performs a certain action of economic or managerial nature in favour of another entity } \\
\text { (to perform work, to transfer property, to pay money, to provide information, etc.), or refrains } \\
\text { from certain actions, and another entity (the controlled party, including the creditor). } \\
\text { It has the right to demand from the obliged party to fulfil its duty. }\end{array}$ \\
\hline The Civil Code of Ukraine & $\begin{array}{l}\text { The liability is a relationship in which one party (the debtor) is obliged to make a certain } \\
\text { action in favour of the other party (creditor) (to transfer the property, to perform work, to } \\
\text { provide a service, to pay money, etc.) or to refrain from committing a certain action (negative } \\
\text { obligation) and the creditor has the right to demand from the debtor fulfilment of his duty. }\end{array}$ \\
\hline $\begin{array}{l}\text { National Accounting Provision (Standard) } \\
1 \text { "General Requirements for Financial }\end{array}$ & $\begin{array}{l}\text { Liability - an enterprise debt that arose as a result of past events and whose recovery in the } \\
\text { future is expected to lead to a reduction in the company's resources that embody economic } \\
\text { benefits. }\end{array}$ \\
\hline $\begin{array}{l}\text { International Accounting Standard } 37 \\
\text { Provisions, Contingent Liabilities and } \\
\text { Contingent Assets }\end{array}$ & $\begin{array}{l}\text { Liability is an existing obligation of an entity that results from past events and the settlement } \\
\text { of which, in expectation, will result in the extinction of the entity's resources, which embody } \\
\text { economic benefits. }\end{array}$ \\
\hline
\end{tabular}

Source: formed by Order of the Ministry of Finance of Ukraine, 2012; Law of Ukraine, 2003; Law of Ukraine, 2003; International Accounting Standard, 2012 
seller's obligation to convey to the buyer the goods sold to him (Mykhaylyshyn, 2012).

From an economic point of view, an obligation is considered as payable, which greatly narrows this concept. However, it is in this interpretation that it is used by accountants-practitioners. In the account of an obligation - this is the source of the formation of financial resources to finance the operational, investment, and financial activities of the enterprise. In the future, arrears on liabilities should be repaid by transferring certain assets or services. Thus, the obligation is the claims of creditors in relation to the assets of an enterprise. The presence of liabilities (debts) reduces the economic requirements of the enterprise and its capital. In civil and commercial law, an obligation arises from a contract, regardless of whether certain actions have already taken to fulfil it (Mykhaylyshyn, 2012).

In the account at the time of signing the contract, the liability is not reflected. That is, only those liabilities that arise from the execution of contracts are reflected in the account, but not at all from the contracts itself. For example, the company concluded a contract for the supply of goods. In accounting, the requirement for these goods and the obligation to pay them do not receive any reflection. An accountant may not guess about the existence of such liabilities. And only after the start of the contract: after the first delivery or payment (prepayment), the accountant begins to reflect the facts of economic life (Mykhaylyshyn, 2012).

Thus, it can be argued that the liabilities are inherent in certain characteristics:

- from the point of view of the law - establishes the grounds for liabilities and the procedure for making settlements;

- from the economic point of view - determines monetary relations and, as a result, the emergence of payables to counterparties;

- accounting - documented the consequences of the implementation of the terms of specific contracts and summarizes the information in the system of accounts and reporting.

Hence the conclusion - all liabilities that are the subject of accounting have legal and economic content. Therefore, in accounting practice, along with the definition of "obligation", the terms "indebtedness" and "settlements" are used.

Quite often, the contents of the category debts are compared with debts or liabilities. Given the economic and legal content of these concepts, we can conclude that identification is unacceptable.

Successfully notes O. V. Chornenka that payables are defined as the result of the legal relationship of the entity, which is the result of committing a certain action of one entity to another entity, an individual, the state, an extra-budgetary fund for the transfer of inventory, cash or other assets, provision of services, performance of works, or actions of legislative and regulatory documents (arrears of taxes or other mandatory payments to the budget and extra-budgetary funds) and gives the creditor the right to claim (Chornenka, 2017).

The affirmation of N. V. Potryvaeva is that calculations are acts of disposal of own funds in favour of another person or receiving funds from another person, ensure the implementation of economic relations between people, producers, and consumers, etc. on the movement of results of labour received not for their own consumption but for the satisfaction of public needs. It is the calculations accompany the exchange process, through which commodity producers, intermediaries, and sellers enter into relationships with consumers (Potryvayeva, Parakonna, 2016).

O. M. Petruk believes that arrears or calculations are reflected in accounting as debts, payments, that is, the promise of payment for actually delivered inventory or services provided. If we promise to pay the buyer, then the account should reflect the promise of the contractor to put the goods, which can also be a valuation. In this case, the fact is actually about the accounting of a bilateral promise - a treaty. If all components of a bilateral legal commitment are reflected in the accounting, we conclude that it is also accounted for. The difficulty in understanding this phenomenon is that the civil law obligation is bilateral, so a certain part of the legal obligation must be shown separately from the creditor, and the other - separately from the debtor. Their reflection in the account takes place through the system of double entry - the fundamental method of accounting since in transactions, there always is a lender and a debtor (debit and credit). All cases of existence and use of double entry cannot be explained by purely economic reasons because there is a legal basis for conducting business operations (Petruk, 2012).

The conducted research makes it possible to substantiate the essence of the category of "liability" (Figure 3).

In our opinion, the liability is a legal relationship between economic entities, which causes the occurrence of indebtedness under certain calculations.

\section{National and international accounting experience and classification of current liabilities}

In accordance with accounting standards, liabilities are divided into: long-term; current; contingent liabilities; income of future periods (Act of the Ministry of Finance of Ukraine, 2000).

A liability is recognized if its valuation can be reliably determined and there is a likelihood of a future decrease in future economic benefits arising from its repayment (Act of the Ministry of Finance of Ukraine, 2000).

Having analysed the normative documents by scientists, the main characteristics of the liabilities were substantiated: 


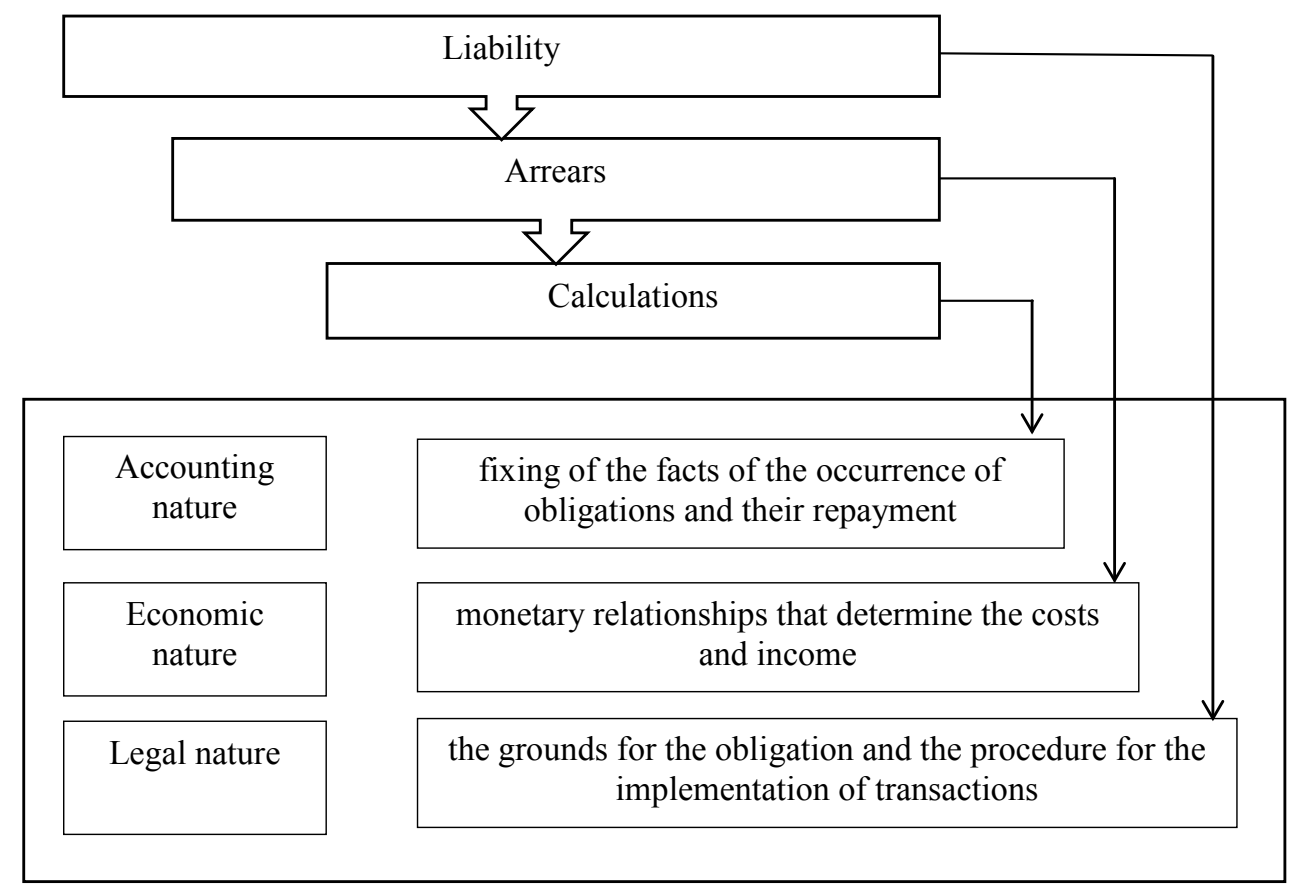

Figure 3. The author's interpretation of the category of "commitment"

Source: substantiated by the author

- specific economic resources (returns are subject to resources or their monetary equivalent - depending on the terms of the contract);

- address (resources are returned to the lender or another third party on behalf of the lender);

- the maturity of the debt;

- remuneration for the use of resources;

- sanctions and violations of contractual liabilities in terms and amounts of debt repayment (Myronova, Batsman, Yatsenko, 2016).

One of the controversial issues in the research of scholars is the divergence of views on the classification of liabilities, including current ones.

Scientists and accounting practices confirm that the classification of company liabilities by individual types is necessary to ensure their management and the objectivity of the presentation of information in the financial statements for decision-making by users.

Honestly, L. V. Chizhevska notes that the first step in achieving the definition of objects is their classification based on the general phenomenon of the unity of opposites (Chyzhevska, Zelenina, 2011).

According to N. R. Dombrovska, scientific classification is a method of studying a plurality of objects by their division into groups according to the general sign of the way of knowing the essence, content, degree of similarity, and differences of objects (Dombrovska, 2014).

In accordance with the Accounting Provision (Standard) 11 "Liabilities", current liabilities include: short-term bank credits; current indebtedness under long-term liabilities; short-term bills issued; accounts payable for goods, works, services; current payable on payments (from received advances, with the budget, from extrabudgetary payments, insurance, with wages, with participants, from internal settlements); current provision; other current liabilities (Act of the Ministry of Finance of Ukraine, 2000).

A special kind of current liabilities is collateral. Usually, they are created to recover future operating expenses for: payment of holidays to employees; additional pension provision; performance of warranty liabilities; restructuring, fulfilment of liabilities upon the termination of activity; execution of liabilities on burdensome contracts, etc. (Act of the Ministry of Finance of Ukraine, 2000).

In the current account liability, an unplanned obligation is also specified in the accounting standards: 1) an obligation that may arise as a result of past events and whose existence will be confirmed only when one or more uncertain future events occur or are not going to happen, over which the enterprise has no full control; or 2) the present obligation that arises from past events but is not recognized as it is unlikely that the obligation to settle will require the use of resources that embody economic benefits or because the amount of the obligation cannot be reliably determined (Act of the Ministry of Finance of Ukraine, 2000).

Contingencies that will become real if there is or will not happen in a future event (for example, before a court makes a decision on the amount of penalties) are recorded in the off-balance sheet account 
042 "Contingent Liabilities" (Order of the Ministry of Finance of Ukraine, 1999).

In addition, the structure of enterprise liabilities can be supplemented by financial liabilities. They are potential opportunities for the entity to provide security. However, clear and precise explanations regarding the accounting of financial liabilities $\mathrm{P}(\mathrm{S}) \mathrm{A} 13$ does not provide (Order of the Ministry of Finance of Ukraine, 2001).

We agree with the opinion of V. O. Ganusich that the controversial issue in accounting for current liabilities is the presence in their composition of incomes of future periods. It is known that future period income is the income received in the current reporting period, but which relates to future reporting periods. There is a contradiction here, because they do not correspond to any of the signs of liabilities, but belong to them (Hanusych \& Loya, 2015).

In foreign scientific literature, current liabilities are divided by degree of probability into actual, estimated, and conditional. In particular, B. Needles, H. Anderson, D. Caldwell give such a characteristic to these types of liabilities:

1) Actual - arise from a contract or legislation. They can be calculated accurately. Actual liabilities include debts on accounts, promissory notes, dividends to pay, sales tax, payroll, etc.

Table 4

Display of current liabilities in the Balance Sheet (Statement of financial position (Form N1))

\begin{tabular}{|l|c|c|}
\hline \multicolumn{1}{|c|}{ The title of the balance sheet } & $\begin{array}{c}\text { Line code in the } \\
\text { balance sheet }\end{array}$ & $\begin{array}{c}\text { Account } \\
\text { code }\end{array}$ \\
\hline Short-term bank credits & 1600 & 60 \\
\hline Promissory notes issued & 1605 & 62 \\
\hline $\begin{array}{l}\text { Current payables for: } \\
\text { long-term liabilities }\end{array}$ & 1610 & 61 \\
\hline goods, work, services & 1615 & 63 \\
\hline Payments to the budget & 1620 & 64 \\
\hline incl. from income tax & 1621 & \\
\hline insurance payments & 1625 & 65 \\
\hline payroll calculations & 1630 & 66 \\
\hline $\begin{array}{l}\text { Current payables to received } \\
\text { advances }\end{array}$ & 1635 & 681 \\
\hline $\begin{array}{l}\text { Current payables to settlements } \\
\text { with participants }\end{array}$ & 1640 & 67 \\
\hline $\begin{array}{l}\text { Current payables to internal } \\
\text { settlements }\end{array}$ & 1645 & 682 \\
\hline $\begin{array}{l}\text { Current payables to insurance } \\
\text { activities }\end{array}$ & 1650 & 65 \\
\hline Current provision & 1660 & 47 \\
\hline Deferred income & 1665 & 69 \\
\hline $\begin{array}{l}\text { Deferred commission income from } \\
\text { reinsurers }\end{array}$ & 1670 & 49 \\
\hline $\begin{array}{l}\text { Other current commitments } \\
\text { Total section }\end{array}$ & 1690 & 685 \\
\hline Xorcer Ordef & X & 672 \\
\hline
\end{tabular}

Source: Order of the Ministry of Finance of Ukraine, 2012; Order of the Ministry of Finance of Ukraine, 1999
2) Estimated - it is an obligation, the exact amount of which cannot be determined before a certain date. Examples of such liabilities are taxes on income, payment of warranty liabilities, and holiday pay.

3) Conditional - non-existent liabilities. Nevertheless, they are potential liabilities because they depend on the future event arising from the previous agreement. Conditional liabilities are classified into permissible, probable, possible (Needles, Andersen \& Caldwell, 1994).

When assessing the content of the national accounting standards, we consider that current liabilities are reflected in the liability of the balance sheet for the respective objects (types) (Table 4 ).

The data in Table 4 indicates that the informational content of the balance in terms of current liabilities for all users is satisfactory. Both external and internal users of the information can carry out a general risk analysis and the possibility of loss due to default. More detailed information for managing the attracted capital can be obtained by internal users using separate internal reporting forms that are developed taking into account the specifics of each entity's activity separately.

Studies conducted confirm that the financial and economic activity of enterprises leads to the emergence of many types of liabilities and a large number of creditors. The organization and accounting of liabilities, as well as their correct presentation in financial statements, depend on how well the division and classification of the objects of accounting were correctly carried out, as well as on the correct classification of the characteristics (Travinska, 2018).

Therefore, it is appropriate to consider that each business entity should establish a system for recording short-term liabilities in such a way that it records as quickly as possible the accounting information on the presence and movement of current liabilities at the enterprise. Because the data on the commitment is the basis for making managerial decisions and conducting further control and analysis of the state of the enterprise. Therefore, every entity must continuously carry out activities to improve the accounting of short-term liabilities (Potryvayeva, Parakonna, 2016).

In order to correctly determine the company with the choice of one or another feature of the classification of liabilities, it is important to weigh the sources of its origin and remember that its basis is not only the accounting origin but, above all, a series of legal relationships that leads to the emergence of the relationship. Considering the classification features of different scholars, and different approaches to the classification of liabilities, one can see that some of them are based on the legal basis of origin. So, before assigning an obligation to one or another kind, it is necessary to substantiate its character and to follow a series of relations that arise with the counteragent (Rasenko, 2012).

In international accounting standards, the liabilities, depending on their essence and the concept of a liability 
Table 5

Comparison of the content of liabilities under national and international accounting standards

\begin{tabular}{|c|c|c|c|c|}
\hline $\begin{array}{l}\text { Determination } \\
\text { procedure }\end{array}$ & Invoice plan & $\begin{array}{l}\text { Accounting Provision } \\
\text { (Standard) } 11\end{array}$ & Content & $\begin{array}{c}\text { International Accounting } \\
\text { Standard } 37\end{array}$ \\
\hline Realistic & Accounts $60-68$ & Current liabilities & Accounting for all current liabilities & $\begin{array}{l}\text { Constructive } \\
\text { commitment }\end{array}$ \\
\hline \multirow{3}{*}{ Potential } & $\begin{array}{l}\text { Off-balance sheet } \\
\text { account } 04\end{array}$ & Contingent liabilities & $\begin{array}{l}\text { Accounting of reasonable amounts of claims, } \\
\text { fines, penalties, etc., the decision on their recovery } \\
\text { is considered in court }\end{array}$ & Conditional obligation \\
\hline & Account 47 & Current provision & $\begin{array}{l}\text { Accounting for the provision of vacations, } \\
\text { warranty, material incentives, etc. }\end{array}$ & Software \\
\hline & Not provided & Not provided & Accounting contracts & Legal obligation \\
\hline
\end{tabular}

Source: the author's interpretation

event, are classified in (International Accounting Standard 37): legal obligation; constructive obligation; contingent liabilities; provision.

Therefore, in order to balance the discrepancy between the time of accounting and legal liabilities, some foreign researchers propose to recognize the obligation at the time of conclusion of contracts, which would lead to the appearance of forecast lines in the balance sheet and, in their opinion, would increase the interest of investors (Rasenko, 2012).

It can be stated that the emergence of additional articles such as contingent assets or contingent liabilities will not lead to an increase in the investment attractiveness of an enterprise, because they cannot be shown on a balance sheet on a prudent basis. Disclosure of such information in the notes on the basis of the example of other off-balance sheet items will only give extra trouble to accountants who will be forced to further track the closing of such accounts in the performance of their liabilities. According to scientists, the existing practice of accounting for liabilities is expedient and effective, and the disclosure of contracts that are expected to be executed in the notes, as part of the report of directors, in projects is adequate to the international requirements for the organization of accounting (Hevlych, Katranzhy, 2017).

The conducted study makes it possible to compare the content of current liabilities defined by national and international accounting standards and justify its own approach in the classification of current liabilities (Table 5).

Consequently, it can be stated that all current liabilities are divided into real and potential: all current liabilities on which the entity makes certain calculations are actual; contingent liabilities and legal liabilities that cause the consideration of amounts of liabilities specified in the contracts are conditional; the collateral that is a part of the current one is estimated.

In order to open an account for the management of the attracted capital, we consider it appropriate to substantiate the order of displaying information on current liabilities at all stages of the accounting process.
The first stage in accounting for current liabilities is the initial generalization of the occurrence of arrears, which will lead to settlements. Its essence is characterized by a documentary reflection of the consequences of the implementation of the terms of the concluded contracts.

The second stage of the accounting process is the current accounting, which is the process of registration of primary accounting data in the system of accounts and registers of synthetic and analytical accounting.

The final stage of the accounting process is final. It can be characterized as the formation of the reporting indicators for a certain period and providing users with the final information in the relevant reporting forms, in particular, the external: Balance Sheet (Statement of financial position) and the Notes to the financial statements for each type of contingent liability, the following information is provided: brief description of the obligation and its amount; uncertainty as to the amount or maturity; amount of expected repayment of obligation by the other party; internal - in self-developed reports, tables, forms, etc. at the enterprise.

Thus, the basis of the management accounting for the attracted capital is the primary documents, accounting data and generalized forms of internal and external reporting.

\section{Findings}

Our research gives grounds for expressing the opinion that in the scientific literature various, approaches to the classification of current liabilities are highlighted. However, taking into account the norms of accounting standards and the needs of internal users since they only need detailed information on current liabilities, we propose the following classification for management purposes:

1) by the form of engagement: commodity: for products and goods; for services, for work; money: from wages, taxes and fees, financial transactions, etc.

2) by object(s): liabilities to banks, bills, suppliers and contractors, taxes, insurance, employees, participants, etc.; 3) by way of repayment: monetary, non-monetary; 
4) by type of activity: operational, financial, liabilities that arose due to another type of activity;

5) by the possibility of evaluation: actual, estimated, conditional;

6) by maturity: up to three months, from three to six months; from six to twelve months;

7) depending on the order of determination: real and potential.

This approach will enable business entities of various fields of activity and forms of ownership to detail analytical accounts of liabilities and develop forms of internal reporting for operational analysis, control and, in general, effective management and rational decisionmaking.

\section{Conclusions}

The conducted research shows that there is no uniform approach to the categorical and conceptual framework of the studied terms "attracted capital", "liability", "debt", "calculations" both in the scientific and economic literature and in normative documents. In view of this, we have argued our own vision of the content of the definition of the obligation as a legal relationship between economic entities, which predetermine the emergence of indebtedness under certain calculations. Current liabilities in various forms of engagement ensure the implementation of business activities of the enterprise and, in fact, are a part of the attracted capital.

A comparison of the components of current liabilities presented in national and international accounting standards has led to the substantiation of their own approach to their classification. Identification of classification features (by the form of engagement, by type, by way of repayment, by type of activity; by the possibility of evaluation; by maturity, depending on the order of determination) will affect the effective management of borrowed capital in terms of current liabilities.

\section{References:}

Wasiuzzaman, S. (2015). Working Capital and Profitability in Manufacturing Firms in Malaysia: An Empirical Study, Global Business Review, 16(4), 545-556. Retrieved from: https://doi.org/10.1177/0972150915581098

Akademichnyy tlumachnyy slovnyk [Academic Explanatory Dictionary]. Retrieved from: http://sum.in.ua (accessed 16 July 2018).

Current liabilities and provision of enterprises of Ukraine by types of economic activity: State Statistics Service. Retrieved from: http://www.ukrstat.gov.ua

Mykhaylyshyn, N. P. (2012). Sutnist zobovyazan ta yikh klasyfikatsiya: ekonomichnyy ta pravovyy aspekty [The essence of the commitments and their classification: economic and legal aspects]. Economics: realities of time, 2(3), 130-135.

Ala'a Adden Abuhommous (2017). "Partial adjustment toward target accounts payable ratio", International Journal of Islamic and Middle Eastern Finance and Management, 10(4), 484-502. Retrieved from: https://doi.org/10.1108/ IMEFM-01-2017-0019

Jiri Chod (2017). Agency Cost of Debt: A Case for Supplier Financing Foundations and Trends(R) in Technology, Information and Operations Management, 10(3-4), 220-236. Retrieved from: ttp://dx.doi.org/10.1561/0200000061

Katarzyna, Ś. (2015). Risk in providing accounting services in the context of new regulations regarding liability insurance (OC) in Poland. Journal of Finance \& Accounting, 4(1), 173-185. Retrieved from: http://dx.doi.org/10.12775/CJFA.2015.012

Zelenina, O. O. (2012). Accounting and analysis of the formation and use of borrowed capital. Extended abstract of candidate 's thesis: 08.00.04. Zhitomir State Technological University. (in Ukrainian)

Natsionalne polozhennya (standart) bukhhalterskoho obliku 1 "Zahalni vymohy do finansovoyi zvitnosti": Nakaz Ministerstva Finansiv Ukrayiny vid 25.01.2012. № 52 [National Accounting Standard (Standard) 1 "General Requirements for Financial Statements": Order of the Ministry of Finance of Ukraine dated January 25, 2012 No. 52]. Retrieved from: http://zakon2.rada.gov.ua/laws/show/z0336-13 (in Ukrainian)

Hospodarskyy kodeks Ukrayiny: Zakon Ukrayiny vid 16.01.2003. № 436-IV [Economic Code of Ukraine. Law of Ukraine dated January 16, 2003, No. 436-IV]. Retrieved from: http://zakon2.rada.gov.ua/laws/show/436-15 (in Ukrainian)

Tsyvilnyy kodeks Ukrayiny: Zakon Ukrayiny vid 16 sichnya 2003. № 435-IV [Civil Code of Ukraine. Law of Ukraine dated January 16, 2003 No. 435-IV]. Retrieved from: http://zakon.rada.gov.ua (in Ukrainian)

Mizhnarodnyy standart bukhhalterskoho obliku 37 "Zabezpechennya, umovni zobovyazannya ta umovni aktyvy" [International Accounting Standard 37 "Provisions, Contingent Liabilities and Contingent Assets"]. Retrieved from: http://zakon3.rada.gov.ua/laws/show/929_051 (in Ukrainian)

Richard, B., McGeachin, A. (2013). Why is there inconsistency in accounting for liabilities in IFRS? An analysis of recognition, measurement, estimation and conservatism. Accounting and Business Research, 43(6), 579-604. Retrieved from: https://doi.org/10.1080/00014788.2013.834811

Chornenka, O. B. (2017). Analiz naukovykh pidkhodiv shchodo sutnosti kredytorskoyi zaborhovanosti ta yiyi klasyfikatsiyi [Analysis of scientific approaches to the nature of accounts payable and its classification]. Proceedings, 2(55), 207-217. 
Potryvayeva, N. V., Parakonna, A. A. (2016). Zobovyazannya i rozrakhunky: ekonomichna ta yurydychna sutnist katehoriy [Commitments and calculations: the economic and legal nature of the categories]. Hlobalni ta natsionalni problemy ekonomiky, 14, 997-1000. Retrieved from: http://global-national.in.ua/archive/14-2016/200.pdf (accessed 10 July 2018).

Petruk, O. M. (2012). Oblikove vidobrazhennya dohovirnykh zobovyazan pry pererobtsi davalnytskoyi syrovyny [Accounting reflection of contractual obligations in the processing of tolling raw materials]. Efektyvna ekonomika. Retrieved from: http://www.economy.nayka.com.ua/?op=1\&z=1102 (accessed 1 October 2018).

Polozhennya (standart) bukhhalterskoho obliku 11 "Zobovyazannya ": Nakaz Ministerstva finansiv Ukrayiny vid 31.01.2000 r. № 20. [Regulation (standard) of accounting 11 "Liabilities ". Act of the Ministry of Finance of Ukraine dated January 31, 2000 No. 20]. Retrieved from http://zakon3.rada.gov.ua/laws/show/z0085-00

Myronova, Yu. Yu., Batsman, Yu. M., Yatsenko, V. V. (2016). Pidkhody shchodo sutnosti, klasyfikatsiyi ta otsinky potochnykh zobovyazan u systemi bukhhalterskoho obliku pidpryyemstva [Approaches to the essence, classification and assessment of current liabilities in the enterprise accounting system]. Herald of ONU named after I. I. Mechnikov, 21(5), 201-205.

Chyzhevska, L. V., Zelenina, O. O. (2011). Pozychkovyy kapital yak intehrovanyy obyekt bukhhalterskoho obliku [Loan capital as an integrated object of accounting]. Bulletin of Economic Science of Ukraine, 1, 164-169.

Dombrovska, N. R. (2014). Debitorska ta kredytorska zaborhovanosti: problemy klasyfikatsiyi [Accounts Receivable and Accounts Payable: Classification Problems]. Innovative economy, 1(50), 182-187.

Plan rakhunkiv bukhhalterskoho obliku aktyviv, kapitalu, zobovyazan i hospodarskykh operatsiy pidpryyemstv i orhanizatsiy: Nakaz Ministerstva finansiv Ukrayiny vid 30.11.99 r. № 291 [Plan of accounting of assets, capital, liabilities and business operations of enterprises and organizations. Order of the Ministry of Finance of Ukraine dated November 30,99, No. 291]. Retrieved from: http://zakon2.rada.gov.ua/laws/show/z1557-11 (in Ukrainian) Polozhennya (standart) bukhhalterskoho obliku 13 "Finansovi instrument": Nakaz Ministerstva finansiv Ukrayiny vid 30.11.2001 r. № 559 [Regulation (Standard) of Accounting 13 "Financial Instruments": Order of the Ministry of Finance of Ukraine dated November 30, 2001 No. 559]. Retrieved from: http://zakon2.rada.gov.ua/laws/ show/z1050-01 (in Ukrainian)

Hanusych, V. O., Loya, M. I. (2015). Vdoskonalennya obliku potochnykh zobovyazan [Improvement in accounting of current liabilities]. Scientific herald of Uzhgorod University, 1(45), 238-241.

Needles, B., Andersen, H., Caldwell, D. (1994). Printsipy bukhgalterskogo ucheta [Principles of accounting]. (Y. Sokolova, Trans). Moscow: Finance and Statistics. (in Russian)

Travinska, S. I. Klasyfikatsiya potochnykh zobovyazan v zakonodavstvi ta bukhhalterskomu obliku [Classification of current liabilities in legistation and accounting]. Retrieved from: http://zbirnuk.bukuniver.edu.ua/issue articles/31.pdf (accessed 10 July 2018).

Rasenko, V. M. (2012). Osoblyvosti klasyfikatsiyi zobovyazan pidpryyemstv [Features of the classification of obligations of enterprises]. Bulletin of social and economic research, 2(45), 163-170.

Hevlych, L. L., Katranzhy, L. I. (2017). Osoblyvosti pidkhodiv do vyznachennya sutnosti "potochni zobovyazannya" ta yikh klasyfikatsiyi [Peculiarities of approaches to the definition of the essence of "current liabilities" and their classification]. Finance, accounting, banks, 1, 70-78. 